\title{
Air tamponade of the heart
}

\author{
Janusz J. Gołota ${ }^{1}$, Tadeusz Orłowski², Katarzyna Iwanowicz ${ }^{3}$, Jadwiga Snarska ${ }^{3}$ \\ ${ }^{1}$ Clinic of Thoracic Surgery, Municipal Hospital, Olsztyn, Poland \\ ${ }^{2}$ Clinic of Surgery, Institute of Tuberculosis and Lung Diseases, Warsaw, Poland \\ ${ }^{3}$ Department of General Surgery, Faculty of Medical Sciences of the University of Warmia and Mazury, \\ Olsztyn, Poland
}

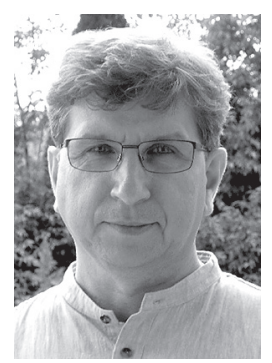

Kardiochirurgia i Torakochirurgia Polska 2016; 13 (2): 150-153

\begin{abstract}
Pneumopericardium is a rare disease defined as the presence of air or gas in the pericardial sac. Among the etiological factors, the following stand out: chest trauma, barotrauma, air-containing fistulas between the pericardium and the surrounding structures, secondary gas production by microorganisms growing in the pericardial sac, and iatrogenic factors. Until now, spontaneous pneumopericardium has been considered a harmless and temporary state, but a review of clinical cases indicates that the presence of air in the pericardium can lead to cardiac tamponade and life-threatening hemodynamic disturbances. We present the case of an 80-year-old patient with a chronic bronchopericardial fistula, who suffered from a cardiac arrest due to air tamponade of the heart.
\end{abstract}

Key words: lung cancer, pericardium, pleura, fistula.

\section{Case report}

The 80-year-old male patient was admitted to the emergency department due to dyspnea; his medical history included cancer of the mouth floor, surgical treatment with subsequent radiation therapy 2 years ago, and many years of smoking. Physical examination revealed resting dyspnea, peripheral cyanosis, numerous bilateral rales and crackles above the lung fields, diminished alveolar murmur above the right lung field, tachycardia, and dull heart sounds. Based on chest X-ray images (Fig. 1), right-sided pneumothorax was diagnosed; the patient was admitted to the Department of General Surgery, where he underwent pleural drainage. Follow-up X-ray examination performed on the next day demonstrated expansion of the right lung, numerous atelectatic foci in the right lung field, and fluid levels corresponding to confined air bubbles with fluid (Fig. 2). Despite the improved X-ray image, no improvement was observed in the patient's general condition. The rales and crackles persisted above both lung fields, the drainage had features of air leakage, and the patient did not tolerate

\section{Streszczenie}

Odma osierdziowa jest rzadkim schorzeniem zdefiniowanym jako obecność powietrza lub gazu w worku osierdziowym. Wśród czynników etiologicznych wyróżnia się: uraz klatki piersiowej, barotraumę, przetoki pomiędzy osierdziem a okolicznymi strukturami zawierającymi powietrze, wtórne wytwarzanie gazu przez mikroorganizmy wzrastające w worku osierdziowym i czynniki jatrogenne. Dotychczas uważano, że samoistna odma osierdziowa jest stanem nieszkodliwym i ustępującym, chociaż przegląd przypadków klinicznych wskazuje, że obecność powietrza w worku osierdziowym może prowadzić do tamponady serca z zaburzeniami hemodynamicznymi zagrażającymi życiu. Poniżej przedstawiono przypadek 80-letniego pacjenta z przewlekłą przetoką oskrzelowo-osierdziową, u którego doszło do zatrzymania krążenia wskutek tamponady powietrznej serca. Słowa kluczowe: rak płuca, osierdzie, opłucna, przetoka.

lying down. As there was no clinical improvement, and the patient's severe condition persisted, heart failure was suspected, and echocardiography was performed. Due to the patient's status, the examination was conducted in a sitting position; it revealed the "presence of a meager amount of fluid with gas bubbles in the pericardium, without signs of impaired myocardial contractility". Physical examination revealed no signs of cardiac tamponade. Due to the lack of clinical improvement and a suspicion of pericardial empyema, and considering the lack of unequivocal indications for immediate intervention, the patient was qualified for chest computed tomography (CT) in order to reach a more comprehensive diagnosis, determine the etiology of the air bubbles in the pericardial fluid, and, possibly, perform drainage of the pericardial sac under CT control.

Computed tomography confirmed the presence of air in the pericardial sac (Fig. 3). When the patient assumed a horizontal position during the examination, his condition rapidly deteriorated, leading to a sudden cardiac arrest. Drainage of the pericardial sac was performed im-

Address for correspondence: Dr. Janusz Gołota, Clinic of Thoracic Surgery, Municipal Hospital, al. Niepodległości 44, 10-450 Olsztyn, Poland, phone: +48 510087 490, fax: +48 89 5326357, e-mail: januszgolota@vp.pl 
mediately, evacuating air under pressure, and reanimation was started. Of note was the presence of an air leak in the pericardial drainage, corresponding with the air introduced into the intubation tube. Reanimation was conducted for approximately half an hour, but heart function was not restored. Computed tomography also demonstrated the "presence of pneumothorax in the right pleural cavity, fluid sacs containing a layer of air (empyemas?) and similar sacs (abscesses?) in the parenchyma of the right lung, as well as an extensive area of consolidation (here? infiltrate of another type?) in the upper lobe of the lung".

Pathoanatomical examination revealed the presence of numerous abscesses in the right lung, including one with a fistula leading to the pleural cavity; in the left main bronchus, $2 \mathrm{~cm}$ from the main carina, a fistula leading to the pericardial sac was found: $1.5 \mathrm{~mm}$ in diameter and approximately $14 \mathrm{~mm}$ in length (Fig. 2); in the heart, the examination revealed fibrinous pericarditis, mainly perivascular fibrosis, and destruction of myocardial fibers. Analysis of the segments obtained from the bronchopericardial fistula and its vicinity revealed keratinizing squamous cell carcinoma of the bronchus, infiltrating the pleura, pericardium, and trachea. The findings in other organs included pyelonephritis, metastasis from the bronchial squamous cell carcinoma in the right adrenal gland, chronic intrahepatic cholangitis, as well as cerebral and meningeal edema.

\section{Discussion}

Pneumopericardium is a rare condition defined as the presence of air or other gases in the pericardial sac. It was first described by Bricheteau in 1844. Subsequently, James documented 38 cases in 1904, and Cowen et al. described 43 cases in 1914. In 1931, Shackelford concluded that the presence of air in the pericardium is not harmful based on the analysis of 77 cases. Without encountering hemodynamic disturbances, Oppenheimer evacuated $800 \mathrm{ml}$ of fluid from the pericardial sac and, subsequently, introduced $500 \mathrm{ml}$ of air. A more comprehensive analysis of the presence of air in the pericardium was conducted by Adcock et al:: the researchers noted that hemodynamic disturbances occurred when intrapericardial pressure exceeded the value of $145 \mathrm{~mm} \mathrm{H}_{2} \mathrm{O}$, which corresponds to a rapid introduction of $60 \mathrm{ml}$ of air into the pericardial sac. Maurer et al. demonstrated that the speed with which the air is introduced is the main factor behind the development of cardiac tamponade - if the air enters gradually, the pericardium can contain up to $500 \mathrm{ml}$ without hemodynamic changes. Other studies reported that the pericardium can contain $1000 \mathrm{ml}$ of blood without signs of tamponade [1]. In order to maintain proper hemodynamics, venous pressure must exceed intrapericardial pressure by $35 \mathrm{~mm}$ $\mathrm{H}_{2} \mathrm{O}$. Symptoms of cardiac tamponade develop when intrapericardial pressure exceeds the value of $266 \mathrm{~mm} \mathrm{H}_{2} \mathrm{O}$ [1]. Pneumopericardium was employed therapeutically to treat tuberculous pericarditis with accompanying exudate. Historically, pneumopericardium was also employed for diagnostic purposes in order to distinguish between in-

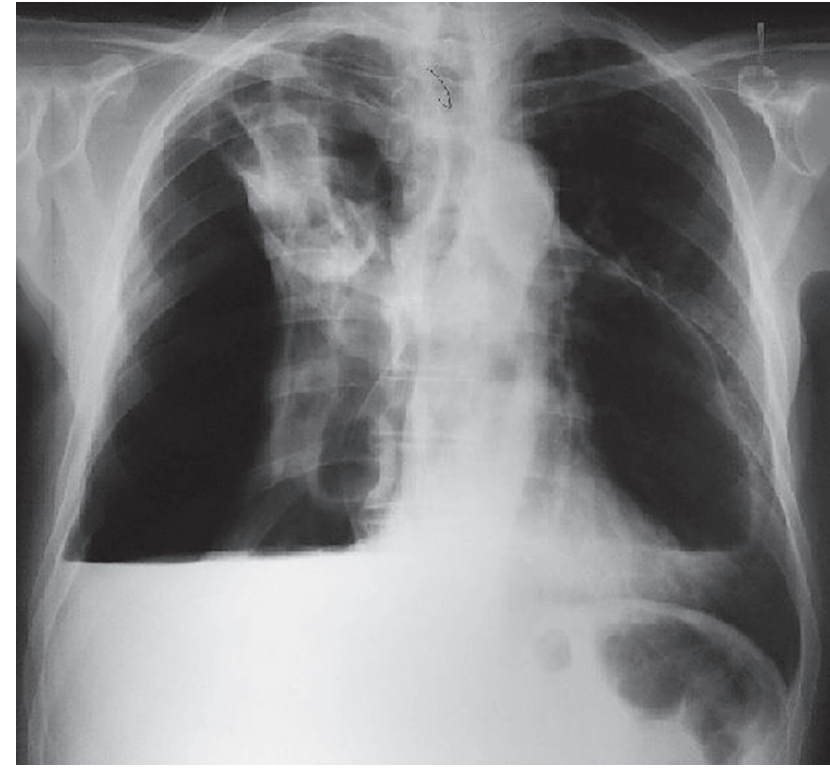

Fig. 1. Chest X-ray before drainage

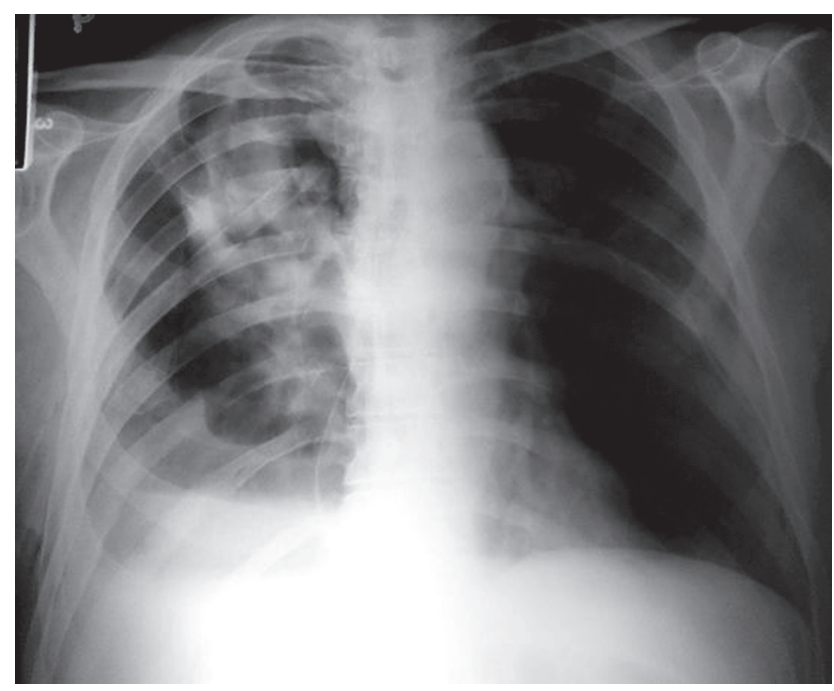

Fig. 2. Follow-up X-ray after pleural drainage

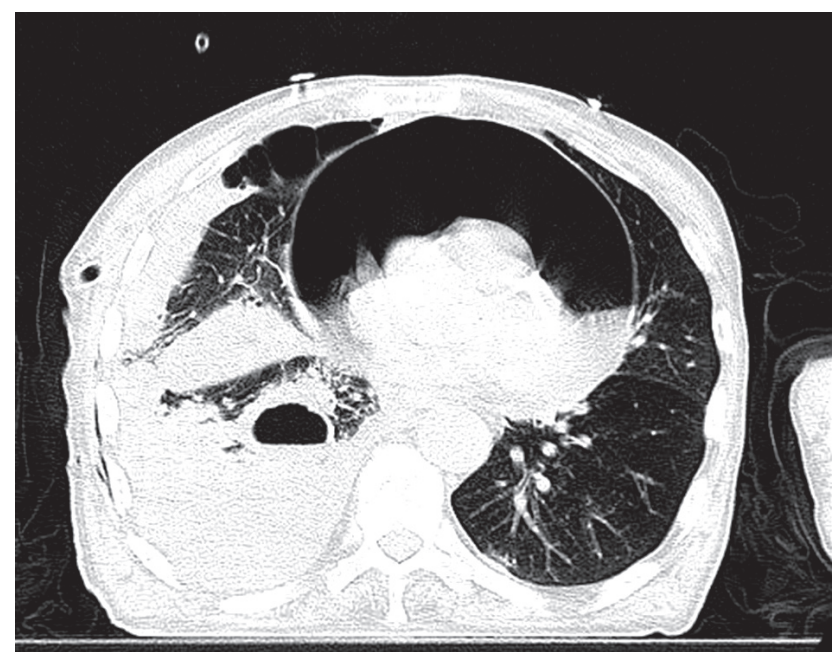

Fig. 3. Computed tomography - pneumopericardium at the level of Th8 


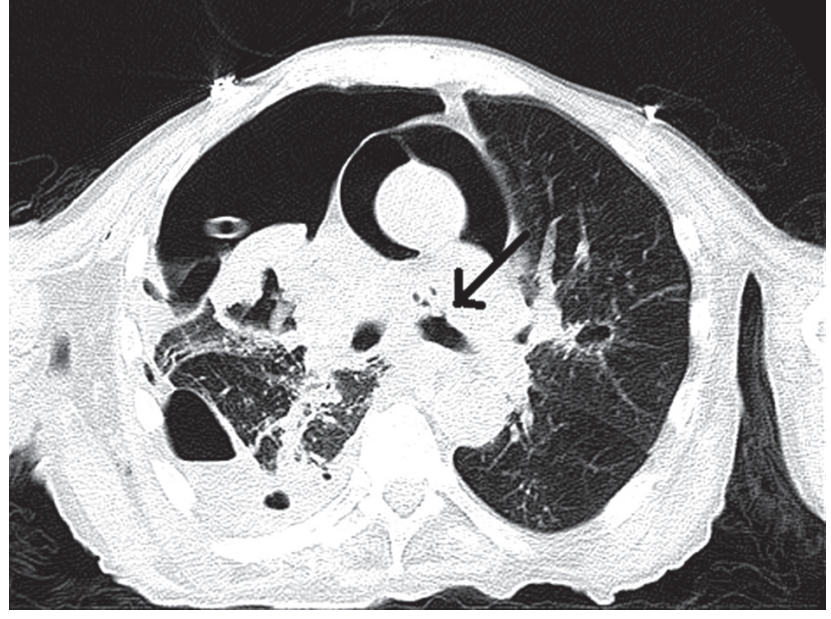

Fig. 4. Computed tomography visualizing the presence of a bronchopericardial fistula

tracardiac and extracardiac lesions, diagnose constrictive pericarditis, or locate foreign bodies within the heart [1] currently, these procedures have been replaced with other diagnostic methods.

The etiology of pneumopericardium can be classified into 4 major types:

1) dull or penetrating chest injury and barotrauma, often caused by positive pressure ventilation (and most often encountered in neonates), severe asthma, prolonged exertion with repeated Valsalva maneuvers, or cocaine inhalation;

2) fistulas between the pericardium and air-containing organs and structures (e.g., the bronchi, esophagus, stomach, an air chamber in the pleural cavity, or a lung abscess);

3) secondary production of gas by bacteria inhabiting the fluid in the pericardial sac, such as Clostridium perfringens or Klebsiella;

4) iatrogenic, e.g., during esophagoscopy or trephine biopsy of the sternum, or after epigastric procedures [1-10].

Pneumopericardium can be symptomatic or asymptomatic. Its classic symptoms include dyspnea and pain in the precardiac area; other symptoms depend on the primary etiology. The literature descriptions of the symptoms are very general; the patient described herein was admitted to the emergency department with symptoms of dyspnea and signs of respiratory insufficiency, which were considered to be caused by pneumothorax after X-ray evaluation of the chest. Despite improving lung aeration, pleural drainage did not result in the expected improvement of general condition, which prompted further diagnostic procedures. Physical examination did not reveal the bruit de moulin symptom, which is very characteristic of the presence of fluid in the pericardial sac. This symptom was first described in 1844 by Bricheteau; during auscultation, he observed that each movement of the heart resulted in a sound that resembled the sound of water splashing on a mill wheel. In the view of the authors of the published case studies, the mill-wheel murmur (or bruit de moulin) is the most consistently occurring symptom of pneumopericardium with the presence of fluid. Choi et al. reported that cardiac auscultation reveals no changes if only a small amount of air is present, as was confirmed by the case of our patient during admission [2].

Chest $X$-ray usually reveals an air-fluid level surrounding the cardiac shadow confined by a thin line representing the pericardial sac (Figs. 1 and 2) [1, 2]. Computed tomography visualizes the presence of air in the pericardium; it can also indicate the cause of pneumopericardium (e.g. when contrast leaks through an esophagopericardial fistula). During the CT examination performed in the present patient, the topogram enabled significantly better visualization of air in the pericardial sac, and the transverse tomograms dispelled all remaining doubts (Figs. 3 and 4).

Electrocardiography can demonstrate symptoms of pericarditis, non-specific changes in ST-T waves, bradycardia, and low voltage of the QRS complex [1]. Echocardiography can demonstrate the presence of an "air fissure" between the chest wall and the heart. In the 6 cases of pneumopericardium evaluation presented by Reid, the presence of air in the pericardial sac had no bearing on the evaluation of intracardiac structures [3]. In the case of our patient, echocardiographic examination revealed no signs of cardiac tamponade or myocardial contractility impairments, and the described air bubbles prompted us to search for a connection with the abscesses in the right lung, which determined the conservative management strategy.

Cummings, in his broad analysis of numerous studies, extending back to 1924, showed that the presence of pneumopericardium is a troublesome condition. In his analysis of the literature, 127 out of 221 patients died (57\%). Among the patients with growing pericardial tension, the mortality rate was $56 \%$ (53 out of 94 patients); $72 \%$ of these deaths (38 out of 53) resulted from air tamponade of the heart [1]. It is noteworthy that most of the described cases pertain to bronchial tree damage resulting from mechanical injury and the use of mechanical ventilators during the neonatal period. If air is present in the pericardial sac without signs of cardiac tamponade, the symptoms of pneumopericardium usually abate on their own, and it is sufficient to treat the underlying disease. It is important for physicians to be aware of this rare, but potentially deadly complication; monitoring the patient's clinical and radiological condition is required $[1,4,5]$. A similar management strategy was adopted in the described patient in order to determine the reason behind the presence of air bubbles in the pericardial fluid.

Mukul employed conservative management in a 14-year-old female patient in whom pneumopericardium developed after coughing in the course of bronchial asthma [4]. Similar conservative management was used by Ozyazicioulu et al. in a 40-year-old female patient after cardiac surgery, in whom pneumopericardium developed due to the aspiration of air through the sternotomy wound [5]. McEachern adopted a conservative approach in a male patient with respiratory insufficiency after CABG, in whom 
the development of pneumopericardium on the $10^{\text {th }}$ postoperative day was caused by mechanical ventilation with continuous positive airway pressure (CPAP). Replacing mechanical ventilation with oxygen supply through an oxygen mask resulted in temporary abatement of the developed pneumopericardium [6]. Roth et al. described the case of a 57-year-old male patient with multi-organ injury resulting from a fall from a height of $10 \mathrm{~m}$; he was diagnosed with pneumothorax and pneumopericardium and treated with pleural drainage. The authors oppose the prophylactic performance of decompression in all cases of pneumopericardium in order to prevent potential gas tamponade; they argue that $2 / 3$ of the patients do not suffer from this complication, and in none of the fatal cases (41.6\%) was pneumopericardium the cause of death. In most patients, pneumopericardium disappears spontaneously [7]. The follow-up X-ray examination performed in our patient revealed lung expansion; our concern and the fact that the patient was qualified for extended diagnostics stemmed from the presence of air bubbles in the scant amount of pericardial fluid and the lack of clinical improvement after pleural drainage. The presence of air bubbles in a small amount of fluid can be suggestive of bacterial etiology. However, the CT examination demonstrated the presence of a significant amount of air, concurrently demonstrating the underlying cause of the air leak into the pericardial sac. Autopsy revealed multi-organ signs of sepsis, the presence of a bronchopericardial fistula, as well as the presence of air and fluid in the pericardial sac.

In case of cardiac tamponade, patient management should strive for pericardial decompression, which can be achieved through the removal of excess air by performing a puncture, incision, or drainage of the pericardial sac. This approach usually restores normal hemodynamic parameters. Access from the vicinity of the costal angle below the xiphoid process is recommended. This management method should be supplemented with antibiotic treatment [1, 5, $6,8,9]$. In the case of our patient, pericardial drainage was prompted by the suspicion of pericardial empyema, which, in turn, resulted from the suspicion of a lung abscess fistula entering the pericardium.

In the literature pertaining to the subject, most space is devoted to cases of pneumopericardium in neonates undergoing mechanical ventilation and in patients in the course of asthma, trauma, or esophagopericardial fistulas resulting from necrotic changes in tumors [1, 4-6, 8-10]. Pneumopericardium in the course of bronchial cancer is an extremely rare complication of the underlying disease. According to Gharwan, only a few such cases had been described in the literature before 2010 [8]. The presence of air in the pericardial sac in the course of bronchial cancer was first described in 1975 by Harris and Kostiner. In 2002,
Gonzales-Juanatey et al. presented a case of bronchial cancer complicated by pneumopericardium during palliative chemotherapy based on gemcitabine and vinorelbine. As the patient did not manifest clinical symptoms of cardiac tamponade, conservative treatment was provided. Palliative chemotherapy was continued without complications, and the air was largely absorbed [10]. In another case of pneumopericardium in the course of lung cancer, reported in 2010, the authors suggested closing the fistula by introducing a stent into the bronchial lumen [8].

The choice of treatment for pneumopericardium depends on the stability of the patient's condition. If the amount of air in the pericardial sac increases, leading to hemodynamic disturbances, the pneumopericardium treatment consists in draining the pericardial sac. In each case, the physicians should strive to treat the cause behind the development of the pericardial fistula. In the present case, the bronchopericardial fistula was chronic; in an upright position, the pressure in the pericardial sac was balanced by the flow of air through the fistula, whereas the patient's assumption of a horizontal position caused the fistula to be closed by the fluid in the pericardium, which resulted in a valve mechanism leading to dynamic accumulation of air in the pericardial sac and cardiac tamponade. As demonstrated by the present case and reports by other authors, the rate at which the symptoms intensify may sometimes preclude successful intervention.

\section{Disclosure}

Authors report no conflict of interest.

\section{References}

1. Cummings RG, Wesly RL, Adams DH, Lowe JE. Pneumopericardium resulting in cardiac tamponade. Ann Thorac Surg 1984; 37: 511-518.

2. Choi WH, Hwang YM, Park MY, Lee SJ, Lee HY, Kim SW, Jun BY, Min JS, Shin WS, Lee JM, Koh YS, Jeon H, Chung WS, Seung K. Pneumopericardium as a complication of pericardiocentesis. Korean Circ J 2011; 41: 280-282.

3. Reid CL, Chandraratna AN, Kawanishi D, Bezdek WD, Schatz R, Nanna M, Rahimtoola SH. Echocardiographic detection of pneumomediastinum and pneumopericardium: the air gap sign. J Am Coll Cardiol 1983; 1: 916-921.

4. Mukul PA, Subhash G, Rajesh J, Vishal S. Spontaneous pneumopericardium in acute asthma. Int J Emerg Med 2010; 3: 141.

5. Ozyazicioulu AY, Balci A. Pneumopericardium associated with a steady cough. Turc J Med Sci 2002; 32: 189-191.

6. McEachern RC, Patel RG. Pneumopericardium associated with face-mask continuous possitive airway pressure. Chest 1997; 112: 1441-1443.

7. Roth TC, Schmid RA. Pneumopericardium after blunt chest trauma: a sign of severe injury? J Thorac Cardiovasc Surg 2002; 124: 630-631.

8. Gharwan H, Erlich RB, Skayrak LA. Non-small-cell lung cancer with bronchopericardial fistula formation. 2010 by American Society of Clinical Oncology.

9. Hymes WA, Itani KM, Wall MJ Jr, Granchi TS, Mattox KI. Delayed tension pneumopericardium after thoracotomy for penetrating chest trauma. Ann Thorac Surg 1994; 57: 1658-1660.

10. González-Juanatey C, Martínez JV, González-Juanatey JR. Pneumopericardium complicating bronchogenic carcinoma. Rev Esp Cardiol 2002; 55: 185. 